\title{
LASER in periodontal treatment: is it an effective treatment or science fiction?
}

\section{Letícia Helena THEODORO(a) (iD) \\ Rosemary Adriana Chiérici \\ MARCANTONIO(b) \\ Mark WAINWRIGHT(c) \\ Valdir Gouveia GARCIA(d)}

(a) Universidade Estadual Paulista - Unesp, School of Dentistry, Department of Diagnostic and Surgery, Araçatuba, SP, Brazil.

(b)Universidade Estadual Paulista - Unesp, School of Dentistry, Department of Diagnostic and Surgery, Araraquara, SP, Brazil.

(c)Liverpool John Moores University, School of Pharmacy \& Biomolecular Sciences, Liverpool, UK.

(d) Latin American Institute of Dental Research and Education - Ilapeo, Curitiba, PR, Brazil.

Declaration of Interests: The authors certify that they have no commercial or associative interest that represents a conflict of interest in connection with the manuscript.

\section{Corresponding Author:}

Letícia Helena Theodoro

E-mail: leticia.theodoro@unesp.br

https://doi.org/10.1590/1807-3107bor-2021.vol35.0099

Submitted: March 12, 2021

Accepted for publication: March 31, 2021

Last revision: April 9, 2021
Abstract: There are several studies that evaluate the use of lasers in periodontal treatment in non-surgical or surgical therapy. However, while several studies showed clinically beneficial effects of some lasers in periodontal treatment, there are few clinical reports of additional advantages of lasers as adjunctive treatments in periodontology. The aim of this paper is to demonstrate and critically analyze the level of scientific evidence of effects of low-level lasers and high-power lasers in periodontology. A narrative review of the studies was carried out in each topic and type of laser or periodontal treatment. In nonsurgical periodontal therapy the results showed that there is an additional clinical benefit when using a diode laser (DL) associated with scaling and root planing (SRP) in patients with moderate to severe periodontitis. The Er:YAG laser seems to be the most suitable for nonsurgical periodontal therapy and promotes the same clinical effects as conventional therapy. In periodontal surgery vaporization of the gingival or mucosal tissue can be carried out with DL, $\mathrm{CO}_{2}$, Nd:YAG, Er:YAG and Er,Cr:YSGG lasers. Photobiomodulation (PBM), mediated by low-level lasers associated with non-surgical periodontal therapy, promotes additional benefits in the short term and accelerates the bone and gingival tissue repair process and also reduces postoperative symptoms of periodontal surgery. The effect of antimicrobial Photodynamic Therapy is relevant in the initial reevaluation periods. Studies have shown controversial results of the use of lasers in periodontics, and this fact may be due to the lack of standard parameters of irradiation in each clinical application.

Keywords: Lasers; Low-Level Light Therapy; Photochemotherapy; Periodontal Diseases.

\section{Introduction}

The word laser is an acronym which means Light Amplification by Stimulated Emission of Radiation. As photonic therapy lasers have been used in periodontics since the 1980s, with the first reports of use in periodontal surgery. ${ }^{1,2}$ The lasers used in periodontics are divided into two groups: high-power lasers and low-power lasers.

High-power lasers (HPL) can be used in soft or bone periodontal surgery and for sulcular debridement of periodontal pocket and root decontamination or as a scaling and root planing (SRP) technique. In non-surgical periodontal treatment, neodymium-doped yttrium/ 
aluminum/garnet (Nd: YAG; 1,064 nm), erbium-doped yttrium/aluminum/garnet (Er:YAG; 2,940 nm), erbium, chromium-doped yttrium/scandium/gallium/garnet (Er,Cr:YSGG; 2,780 nm) and high power semiconductor diode laser (DL) (808-904 $\mathrm{nm}$ ) are the most indicated lasers. ${ }^{2,3}$ Associated effects on root surfaces have been the subject of several studies carried out with carbon dioxide lasers $\left(\mathrm{CO}_{2}\right){ }^{4} \mathrm{Nd}: \mathrm{YAG}^{4}$, diode laser, ${ }^{5,6}$ Er: YAG ${ }^{4,5,6}$ and Er,Cr:YSGG. ${ }^{78,9}$ Low-level lasers (LLL) have been widely used in periodontics due to their tissue photobiomodulation (PBM) action with the objective to reduce inflammation and accelerate the repair process of surgical wounds as well as pain reduction. Moreover, they act as a source of light to activate the photosensitizing dyes (photosensitizers), used in antimicrobial Photodynamic Therapy (APDT), a procedure that has been widely used in periodontics since the decade of the 2000s. PBM was defined as a therapy that uses light in the visible or infrared spectrum, emitted by a laser or an LED (light emitting diode) in order to reduce inflammation, control pain and speed up repair. ${ }^{10}$ Its primary effects occur at the level of the cellular respiratory chain, which result in increased vascularization (angiogenesis), modulation of the immunoinflammatory response and accelerated repair in the treated area. ${ }^{10}$

Although lasers are widespread around the world and are indicated for various conditions in periodontal treatment, several systematic review studies have not proven their clinical benefits, while other studies have questioned their effectiveness and clinical advantages, especially when used as a supporting procedure, not demonstrating significant long-term clinical advantages in terms of improving periodontal clinical parameters and not recommending their use in periodontics. ${ }^{11,12,13}$

In view of these facts, the objective of this article is to discuss the main scientific evidence regarding the use of different lasers in periodontics and to be able to evaluate the degree of scientific evidence in systematic reviews that aimed to evaluate the use of lasers in periodontics. Therefore, it aims to clarify to the scientific community the advantages and limitations of the use of this photonic therapy in periodontal treatment, which used with adequate parameters may constitute an alternative or adjunctive therapy of great clinical applicability, as it is safe and easy to handle for the professional.

\section{Methodology}

\section{Search strategy}

The keywords were defined with searches in the MESH descriptors to form the search strategy. Free terms were also used, as well as combinations such as "Periodontitis", "Chronic Periodontitis", "Periodontal disease", "Photochemotherapy", "Photodynamic therapy", "Lasers", "Photobiomodulation Therapy", "Low-Level Laser Therapy”, "Nd-YAG lasers", “ $\mathrm{CO}_{2}$ lasers", "Carbon dioxide laser", "Er-YAG laser", "YSGG laser", "diode lasers" were searched together in different formats by two authors (RACM and VGG) on PubMed/MEDLINE, SCOPUS, EMBASE, Cochrane Central and Web of Science. The survey was conducted between July and August, 2020. A narrative review of the studies was carried out in each topic and type of laser or periodontal treatment. A manual search of the systematic reviews and meta-analysis papers was also performed from 2015 to August 2020. The level of certainty of systematic reviews was developed following the methodology of the Grading of Recommendations Assessment, Development and Evaluation (GRADE).

\section{Results and Discussion}

\section{High-Power (HPL) in periodontology}

\section{Non-surgical periodontal therapy (Figure 1)}

\section{Nd:YAG and Diode lasers}

With the development of optical fibers, there has been a great advance in the clinical use of HPL, which allowed their use in different indications in periodontics. Among these, the subgingival use of optical fibers, which introduced into periodontal pockets, promote bacterial reduction which, if applied with adequate irradiation parameters, is considered a minimally invasive technique. ${ }^{14}$ Both the Nd:YAG laser and the DL are indicated to remove the sulcular epithelium from the periodontal pocket (sulcular debridement) as well as to promote the reduction of 
periodontopathogenic bacteria, supra- or subgingival. The results of the studies are controversial. While studies that evaluated Nd:YAG laser $(400 \mathrm{~mJ} /$ pulse; $60 \mathrm{~s})^{15}$ and DL (940 nm; $0.8 \mathrm{~W}$ ) as adjuvants in the maintenance therapy of residual pockets did not demonstrate additional clinical benefits, ${ }^{16}$ other studies evaluating the association of the Nd:YAG laser with Er:YAG demonstrated clinical advantages only in deep pockets ${ }^{17}$ and additional clinical and microbiological benefits to SRP in the treatment of patients with moderate to severe periodontitis. ${ }^{18}$

The laser output wavelength and the absorbance of the tissues are two relevant conditions for the action of lasers to occur. The absorption of laser irradiation by biological tissues depends on the presence of proteins, pigments, water-free molecules and other macromolecules. ${ }^{19}$

Scientific evidence has shown that the use of DL on a root surface should be performed with caution, in an interrupted mode and with appropriate parameters, in order not to promote pulp damage. ${ }^{5}$ The clinical effects of DL when used as adjunctive therapy to SRP were evaluated in several studies. ${ }^{20-24}$ The results obtained demonstrated the bacterial reduction of periodontal pathogens..$^{21,23,25}$ However, these findings were not confirmed by other researchers when comparing the use of DL with conventional mechanical treatment. ${ }^{20.22}$ As for the evaluation of clinical parameters, studies have reported greater reduction in probing depth and gain in clinical attachment in areas that have been treated with SRP associated with $\mathrm{DL}^{20,21}$ while other studies have not shown clinical advantages with the use of DL as an adjunct therapy to SRP. ${ }^{22,24}$

An experimental study developed in animals by our research group evaluated the effects of DL $(808 \mathrm{~nm}$; $1 \mathrm{~W}, 20 \mathrm{pps}, 20 \mathrm{~s} /$ tooth, $10 \mathrm{~J}$ ) as monotherapy or as an adjunct therapy to the SRP mechanical treatment in the treatment of experimental periodontitis. Significant reduction in alveolar bone loss, inflammation and acceleration of the periodontal tissue repair process was greater when DL was used as an adjunct to SRP. ${ }^{26}$ When used on a root surface, studies have demonstrated, with scanning electron microscopy evaluation, that DL promoted few morphological changes on the surface when used with adequate parameters and did not alter its biocompatibility.
A systematic review study concluded that DL is more effective in treating probing depth greater than $5 \mathrm{~mm}$, when compared to SRP alone. ${ }^{27}$ However, a consensus of evidence presented through a systematic review demonstrated that there is an additional clinical benefit when using DL associated with SRP in non-surgical periodontal treatment in patients with moderate to severe periodontitis, and the gain of clinical attachment level (CAL), although statistically significant, has modest clinical relevance. ${ }^{11}$

On the other hand, a recent clinical study has shown beneficial effects of the use of DL ( $808 \mathrm{~nm}$; 1.5 to $1.8 \mathrm{~W}$; continuous mode) in the treatment of periodontal disease in type 2 diabetic patients. With the optical fiber positioned inside the periodontal pocket and directed to the soft tissue, it was demonstrated that the combination of the laser and the SRP enabled improvement in the periodontal clinical parameters as well as the reduction of Porphyromonas gingivallis and Aggregatibacter actinomycetemcomitans, compared to treatment with SRP alone..$^{28}$ Reiterating these beneficial effects, a review study comparing the use of lasers in periodontal treatment concluded that among HPL, DL is the second best in promoting gain in CAL at 3 months when used in conjunction with SRP, and the best one in gaining CAL at 6 months of evaluation. ${ }^{29}$ In the case of DL and Nd:YAG, fiber optics have been used in motion for 10 to 30 seconds on the buccal and lingual/palatal surfaces.

\section{Er:YAG and Er,Cr:YSGG lasers}

Er:YAG (2,940 nm) and Er,Cr;YSGG (2,780 nm) lasers are highly absorbed by water molecules within the hydroxyapatite crystals. Therefore, they have a high capacity for removing mineralized tissues as they promote a photomechanical or photothermal effect, they have their own cooling system, and they do not cause heating in adjacent tissues. ${ }^{2,3}$ It is also noted that the Er,Cr:YSGG laser is strongly absorbed by hydroxyapatite.

From the point of view of the morphological aspect of the root surface treated with these lasers, in vitro studies have shown that both Er:YAG and Er,Cr;YSGG lasers promote changes in the surface making them more irregular and rough. $5,6,7,30,31,32$ These changes in the surface result from the explosive ablation process 
typical of these lasers, maintaining biocompatible surfaces when used with parameters adequate irradiation. ${ }^{6,31,33}$ These lasers are also indicated for removal of dental calculus, non-surgical treatment of periodontitis (bacterial reduction) and soft or mineralized tissue ablation procedures. ${ }^{2,3}$ In addition, it has been shown that the Er:YAG laser promotes a reduction in pulp temperature that may also be associated with exterior cooling. ${ }^{5}$

The beneficial effects of using Er:YAG and Er,Cr:YSGG lasers to remove dental calculus and their effects on topography and root surface roughness was demonstrated in a systematic review study that showed that the combination of SRP using the erbium lasers as an adjunctive therapy can be appropriate to remove residual debris from the root surface and have little thermal effect on the root surface. This study concluded that the Er:YAG laser seems to be the most suitable for nonsurgical periodontal therapy. ${ }^{34}$

Some studies have shown that the Er:YAG laser promotes the same clinical effects as conventional SRP therapy, ${ }^{35-39}$ despite promoting greater microbial reduction. ${ }^{18,40}$ In addition, there are a limited number of studies that have evaluated and investigated the clinical effects of lasers as an adjunct treatment to SRP in the treatment of periodontitis..$^{29,40,41,42}$

The Er:YAG laser promotes moderate benefit during periodontal treatment and has been considered an alternative for the treatment of periodontitis. Studies by our group have shown that the Er:YAG laser has the same effect as SRP alone and that used as an adjuvant increases the ability to reduce microorganisms. ${ }^{39,40}$ The parameters most used in clinical studies in humans that evaluated the effect of the Er:YAG laser were pulse energy from 100 to $160 \mathrm{~mJ} /$ pulse and frequency of $10 \mathrm{~Hz}$, to perform root debridement and scaling. A meta-analysis study concluded that the Er:YAG laser as an adjunct therapy to SRP promotes short-term clinical benefits, and promotes less painful sensation in patients. ${ }^{43}$

Histomorphological evaluation of periodontal repair in human biopsies of 21 patients after using the Er:YAG laser as a monotherapy or adjunct to SRP demonstrated that there are no differences in the repair process, with an increase in the proliferation of fibroblasts and collagen maturation between 2 and
6 weeks after treatments, with minimal difference in collagen density and distribution. ${ }^{42}$

The Er,Cr:YSGG laser $(2,780 \mathrm{~nm})$, due to its thermomechanical action, has been indicated for the removal of mineralized tissues. The emitted light is again absorbed by the water contained in the hydroxyapatite matrix of mineralized tissues and, similar to the Er:YAG laser, promotes tissue ablation. It is also associated with the effects produced by the impact on the treated tissue, of the water released by the emitter. ${ }^{19}$ A recent study demonstrated that the Er,Cr:YSGG laser as an adjunctive therapy further reduces clinical inflammation after 1 and 3 months of treatment, when compared to isolated non-surgical periodontal therapy, but there are no differences in the reduction of IL-1B and MMP- $8 .^{44}$ Power of $1.5 \mathrm{~W}$ is considered appropriate for root calculus removal without promoting significant morphological changes. ${ }^{745}$ However, there are few studies that have evaluated the use of this laser as an adjunct therapy to SRP. ${ }^{46-49}$ Another option of periodontal treatment with laser consists of the association of different lasers. The associated use of DL (904 nm, 2 sessions) and Er,Cr:YSGG in subgingival debridement in periodontal pockets with a depth greater than $4 \mathrm{~mm}$, demonstrated greater clinical benefits and bacterial reduction when compared with isolated subgingival debridement. ${ }^{50}$ There are some recent review and meta-analysis studies on HPL for the treatment of periodontal disease and the level of certainty varied from low, moderate to high. 11,12,27,29,43

\section{Surgical periodontal therapy}

The HPL most suitable for soft tissue surgery are $\mathrm{CO}_{2}(10,600 \mathrm{~nm}), \mathrm{Nd}: Y A G(1,064 \mathrm{~nm}), \mathrm{DL}(800-980 \mathrm{~nm})$, Er:YAG (2,940 nm) and Er,Cr:YSGG lasers (2,780 nm). Among its advantages, it is highlighted the promotion of hemostasis and microbial reduction due to the increase in tissue temperature, in addition to being a highly conservative procedure. ${ }^{2,3,14}$

Surgical procedures of excisional biopsy, excisions of pathological soft tissue (granuloma, fibroma), muscle brakes and bridles, corrections of gingival contour and smile, gingivectomy/gingivoplasty, removal of melanic pigmentation, increase of clinical crown, proximal wedge, de-epithelialization of the flap in regenerative procedures, subgingival curettage and 
bacterial reduction in periodontal pockets are the most indicated ones. ${ }^{2,3,14}$ In highly vascularized tissue, the $\mathrm{CO}_{2}$, Nd:YAG and DL are the most indicated for their ability to reduce bleeding during the operation.,14 DL, being absorbed by tissue pigments, promote effective hemostasis of the surgical area, without causing thermal damage in depth. Given that they are portable and of low cost, they have gained the interest of many professionals.

In surgical periodontal therapy, Nd:YAG, DL, Er:YAG and Er,Cr;YSGG lasers have been most used. ${ }^{51-55}$ A systematic review has shown that there is an additional clinical gain in attachment level when using only the Er:YAG laser in surgical periodontal therapy, but the magnitude of this gain is questioned. ${ }^{11}$ Vaporization of the granulation tissue can be carried out with DL, $\mathrm{CO}_{2}$, Nd:YAG applied with appropriate parameters (low) in pulsed or interrupted mode. The debridement of the root surface with these lasers is not indicated, and the Er:YAG and Er,Cr:YSGG lasers are indicated for this purpose.

Animal studies have evaluated the osteotomy and osteoplasty procedure performed with an Er,Cr:YSGG or drill laser. The repair was more favorable when performed with the Er,Cr:YSGG laser, ${ }^{56,57}$ characterized by the absence of tissue carbonization and debris. In addition, it proved to be a safe and precise procedure, capable of controlling the depth of the cut if used with adequate parameters of irradiation, cooling and the inclination of the output beam.

\section{Low-level laser (LLL) in periodontology}

\section{Photobiomodulation (PBM) therapy (Figure 2)}

\section{Non-surgical periodontal therapy}

The lasers used in PBM emit in the visible or near-infrared range (630-980 $\mathrm{nm}$ ) and have important effects in non-surgical periodontal treatment as they contribute to the reduction of the inflammatory process of gingival tissues and develop a photobiomodulatory effect evidenced by the reduction of marker phenotypes associated with activated macrophages, reactive nitrogen species and pro-inflammatory cytokines. ${ }^{10}$

In non-surgical periodontal therapy, PBM therapy has been indicated as an adjunct therapy to the procedure of SRP, for the control of inflammation and for the acceleration of tissue repair in the immediate or mediate postoperative period in periodontal surgeries that affect soft and bone tissue associated or not with the use of regenerative techniques; for the reduction of edema, postoperative pain as well as for the treatment of dentin hypersensitivity. ${ }^{2,58}$ Thus, it can be used as an adjunct to surgical and non-surgical therapy of diseases gingival associated or not with plaque, and in the treatment of periodontitis, especially in the face of unfavorable systemic conditions or modifying factors, such as smoking. ${ }^{58}$

In the treatment of gum disease, laser-mediated PBM as a light source can be used to treat gingival disease in two situations: as an adjunct to mechanical debridement, with the aim of helping to reduce the inflammatory process ${ }^{59}$ or as an auxiliary therapy in the postoperative of areas submitted to surgery of gingival tissue (gingivectomy/gingivoplasty) to accelerate the repair process. ${ }^{58}$ The effectiveness of PBM in controlling inflammation has been demonstrated by several studies both in the treatment of gingivitis ${ }^{60}$ and periodontitis. ${ }^{61-64}$

Randomized controlled clinical studies evaluated the effects of PBM as an adjunct therapy to non-surgical treatment of periodontitis. While some authors reported that there is still no strong evidence on the effectiveness of this therapy when used for this purpose, given the limited number of studies with adequate methodologies ${ }^{59}$ and the heterogeneity of irradiation parameters; other authors reported that the results are promising because they demonstrated beneficial effects of this therapy in the short term. ${ }^{65,66}$

However, experimental studies that evaluated this therapy as an adjunct in the treatment of periodontal disease experimentally induced in animals, proved the effectiveness of PBM. Control and reduction of alveolar bone loss were observed in animals systemically modified by corticosteroids (dexamethasone), ${ }^{67}$ chemotherapy, ${ }^{68,69}$ nicotine, ${ }^{70,71}$ estrogen depletion. ${ }^{72,73}$ The benefits of this therapy are probably due to its ability to promote angiogenesis, proliferation control of the inflammatory process and, consequently, acceleration of the events involved in tissue repair. ${ }^{67}$ Importantly, the number of sessions of this therapy may contribute to a greater control of 


\section{HIGH-POWER LASERS IN PERIODONTICS}

\begin{tabular}{|c|c|c|c|c|}
\hline $\begin{array}{c}\mathbf{C O}_{\mathbf{2}} \\
\text { Wavelength } \\
9,300 \text { and } 10,600 \mathrm{~nm}\end{array}$ & $\begin{array}{c}\text { Diode } \\
\text { Wavelength: } 808 \text { - } 980 \mathrm{~nm}\end{array}$ & $\begin{array}{c}\text { Nd:YAG } \\
\text { Wavelength: } 1,064 \mathrm{~nm}\end{array}$ & $\begin{array}{c}\text { Er:YAG } \\
\text { Wavelength: } 2,940 \mathrm{~nm}\end{array}$ & $\begin{array}{c}\text { Er,Cr:YSGG } \\
\text { Wavelength: } 2,780 \mathrm{~nm}\end{array}$ \\
\hline & $\begin{array}{r}\bullet \text { promote hen } \\
\bullet \text { excisional } \\
\bullet \text { frenulect } \\
\bullet \text { gingival contour and } \\
\bullet \text { gingivectomy / g }\end{array}$ & $\begin{array}{l}\text { sis } \\
\text { sy } \\
\text { corrections } \\
\text { oplasty }\end{array}$ & $\begin{array}{l}\text { - crown lengthenin } \\
\text { • wedge proxima } \\
\text { • subgingival curetta } \\
\text { emoval of melanin pign } \\
\text { ithelialization in regene }\end{array}$ & rocedures \\
\hline \multicolumn{5}{|c|}{ Non-surgical treatment } \\
\hline & Diode & Nd:YAG & Er:YAG & Er,Cr:YSGG \\
\hline & \multicolumn{2}{|c|}{$\begin{array}{l}\text { - removal of the sulcular epithelium of periodontal pocket } \\
\text { (sulcular debridement) } \\
\text { - reduction of periodontopathogenic bacteria (supra or } \\
\text { subgingival) }\end{array}$} & \multicolumn{2}{|c|}{$\begin{array}{l}\text { - removal of mineralized tissue } \\
\text { - removal of dental calculus/biofilm } \\
\text { bacteria reduction of periodontal pocket }\end{array}$} \\
\hline ENERGY & & $100-400 \mathrm{~mJ} /$ pulse & $100-160 \mathrm{~mJ} /$ pulse & $50-100 \mathrm{~mJ} /$ pulse \\
\hline TIME & 20 - 30 seconds/site & $30-60$ seconds/site & From 20 seconds & From 20 seconds \\
\hline $\begin{array}{c}\text { PULSE } \\
\text { REPETITION }\end{array}$ & $10-100$ pps & $10-20 \mathrm{~Hz}$ & $10-20 \mathrm{~Hz}$ & $10-30 \mathrm{~Hz}$ \\
\hline $\begin{array}{c}\text { EMISSION } \\
\text { MODE }\end{array}$ & interrupted & pulsed & pulsed & pulsed \\
\hline POWER & $0.8-2.5 \mathrm{~W}$ & $1.0-2.0 \mathrm{~W}$ & $1.0 \mathrm{~W}$ & $1.0-1.5 \mathrm{~W}$ \\
\hline
\end{tabular}

\begin{tabular}{|c|c|c|c|c|}
\hline \multicolumn{5}{|c|}{ Surgical treatment } \\
\hline & Diode & Nd:YAG & Er:YAG & Er,Cr:YSGG \\
\hline & \multicolumn{2}{|c|}{$\begin{array}{l}\text { - } \text { excisional biopsy } \\
\text { - frenulectony } \\
\text { - gingival contour and gummy smile } \\
\text { - } \text { gingivectomy / gingivoplasty } \\
\text { - } \text { removal of melanin pigmentation } \\
\text { - } \text { inter-proximal surgery } \\
\text { - } \text { second-stage surgery of submerged implants } \\
\text { - flap de-epithelialization in regenerative procedure } \\
\text { - ulectomy/ulotomy }\end{array}$} & \multicolumn{2}{|c|}{$\begin{array}{l}\text { - } \text { excisional biopsy } \\
\text { - } \text { frenulectomy } \\
\text { - gingival contour and gummy smile } \\
\text { - } \text { gingivectomy / gingivoplasty } \\
\text { - } \text { seconol of melanin pigmentation } \\
\text { - osteotomy and osteoplasty } \\
\text { - ulectomy/ulotomy }\end{array}$} \\
\hline ENERGY & & $100-250 \mathrm{~mJ}$ & $100-500 \mathrm{~mJ}$ & $100-400 \mathrm{~mJ}$ \\
\hline POWER & $1.0-4.0 \mathrm{~W}$ & $2.0-4.0 \mathrm{~W}$ & $2.0-4.0 \mathrm{~W}$ & $2.5-4.5 \mathrm{~W}$ \\
\hline $\begin{array}{c}\text { PULSE } \\
\text { REPETITION }\end{array}$ & & $10-20 \mathrm{~Hz}$ & $4-15 \mathrm{~Hz}$ & $15-50 \mathrm{~Hz}$ \\
\hline $\begin{array}{l}\text { EMISSION } \\
\text { MODE }\end{array}$ & Continuou & Pulsed wave & Pulsed wave & Pulsed wave \\
\hline
\end{tabular}

Figure 1. Indications and irradiation parameters of the high-power lasers described in the periodontal studies.

alveolar bone loss, inflammation and modulation of the immunoinflammatory response, which was more favorable after 4 sessions of PBM, with an interval of 24 hours $(660 \mathrm{~nm}, 0,035 \mathrm{~W}, 4 \mathrm{~J}){ }^{68}$

Clinical studies in humans using PBM as an adjunct therapy have revealed a very large discrepancy between the results as well as a significant variation in irradiation parameters. ${ }^{61,62,64,74-81}$ There are also studies that used PBM in multiple sessions ( 3 to 10 sessions), with different wavelengths $(630,632,635,660,670$,
780, 830 and $980 \mathrm{~nm}$ ), with variable energy (0.96 to $10.5 \mathrm{~J}$ per tooth), ${ }^{61,62,64,74-81}$ which makes it difficult to indicate the best treatment protocol.

One of the protocols that proved to be effective, employed an $808 \mathrm{~nm}$ laser with an energy density of $4 \mathrm{~J} / \mathrm{cm}^{2}$ applied in contact mode and punctually on the gingiva on the first, second and seventh day after periodontal treatment. ${ }^{62}$ Another study revealed that PBM as an adjunct to conventional treatment, used in 5 applications $(660 \mathrm{~nm}, 200 \mathrm{~mW}, 60 \mathrm{~s} /$ tooth) was better 
than a single application, showing a reduction in pro-inflammatory mediators and accelerated healing with no difference in clinical periodontal parameters. ${ }^{77}$

Clinical studies have also shown beneficial effects of adjunctive PBM in the treatment of periodontal disease in diabetic patients. Reduction of gingival inflammation was observed when using a $670 \mathrm{~nm}$ laser with a power of $5 \mathrm{~mW}$ for 14 minutes/day, for 5 consecutive days on the gingival tissue. ${ }^{63}$ The use of PBM therapy $(980 \mathrm{~nm})$ was also shown to be effective in nonsurgical periodontal treatment of chronic periodontitis in uncontrolled type $2 \mathrm{DM}$ patients. ${ }^{80}$ PBM therapy was applied $\left(0.5 \mathrm{~J} / \mathrm{cm}^{2}\right)$ on the buccal side of each tooth on the selected side for four sessions: immediately after treatment (day 0 ) and 1, 3 and 7 days after treatment. ${ }^{80}$ The results demonstrated clinical and biochemical benefits in accelerating tissue repair and reducing inflammation..$^{80}$

The benefits of PBM have also been seen in the treatment of periodontal pockets in patients with periodontitis and type 2 diabetes..$^{79}$ Periodontal pockets were treated locally with laser $(660 \mathrm{~nm}$, $0.03 \mathrm{~W}, 22 \mathrm{~J} / \mathrm{cm}^{2}, 20 \mathrm{~s}$, continuous wave, $1.1 \mathrm{~W} / \mathrm{cm}^{2}$, total energy of $0.6 \mathrm{~J}) \cdot{ }^{79}$ The results demonstrated that PBM was more effective in reducing the percentage of moderate periodontal pockets at 6 months in patients with type 2 diabetes. ${ }^{79}$

There are few recent review and meta-analysis studies on PBM for the treatment of periodontal disease and the level of certainty varied from moderate to low. ${ }^{59,66}$ Meta-analysis concluded that the use of PBM, mediated by laser associated with non-surgical periodontal therapy, promotes additional benefit only in the short term. ${ }^{59}$ Meanwhile, another systematic review evaluating the action of PBM therapy as an adjunct in the treatment of aggressive periodontitis demonstrated, after analyzing 4 randomized controlled clinical studies, that PBM promotes a significant reduction in probing depth. In this sense, studies are required with long follow up and standard laser parameters. ${ }^{66}$

\section{Surgical periodontal therapy}

The benefits of using PBM to repair wounds are well documented in the literature in both animal and human studies, ${ }^{82-84}$ mainly for their action on epithelialization after operative procedures..$^{85} \mathrm{PBM}$ can be used in periodontal surgical treatment in order to: promote the repair of gingival and mucous tissues; accelerate bone tissue repair; and reduce postoperative symptoms of periodontal surgery. LLL $\left(\leq 500 \mathrm{~mW}\right.$, energy density $\left.\geq 5 \mathrm{~J} / \mathrm{cm}^{2}\right)$ used as an adjunct to periodontal surgery positively influenced postsurgical pain control. Adjunctive LLL therapy to free gingival grafts can accelerate wound healing of palate sites at early healing phase. ${ }^{86}$ These benefits were more pronounced in conditions of delayed repair process, as in the case of smoking, uncompensated diabetes or in situations of immunosuppression by the use of medication. . $3,87,88$

Randomized controlled clinical study demonstrated that surgical areas of periodontal flap when irradiated in the postoperative period with PBM $(940 \mathrm{~nm}, 0.5 \mathrm{~W}$, continuous, $112 \mathrm{~s}, 20 \mathrm{~J} / \mathrm{cm}^{2} /$ site ), $3 \mathrm{~mm}$ away from the tissue, presented a reduction of pain in the period of 2 to 7 days, and there was a reduction in the need to use analgesics. ${ }^{89}$

In the bone tissue, although there are many studies in different clinical and experimental conditions in animals, there are few studies that have evaluated the effect of PBM on bone repair of periodontal tissues. Clinical study in humans evaluated the effects of PBM $(830 \mathrm{~nm}, 40 \mathrm{~mW}, 60 \mathrm{~s}$, continuous mode, $4 \mathrm{~J} / \mathrm{cm}^{2}$ ) in 4 applications (0 hour, 3, 5 and 7 days) in treated infra-bone defects with bioactive glass. ${ }^{90}$ After 3 months, they observed that PBM improved periodontal repair, without additional benefits 6 months after surgery. ${ }^{90}$ These results confirm that PBM accelerates the bone repair process becoming a promising adjunctive treatment in periodontal regeneration, reiterating the findings of other researchers who observed that PBM is able to stimulate the release of molecules that increase local neoangiogenesis and stimulate the osteoblastic differentiation and bone repair associated or not with biomaterials, due to the ability to stimulate osteogenesis and biomineralization. ${ }^{91,92}$

Regarding the treatment of gingival recessions, a meta-analysis study showed that the association of the flap with the PBM enabled the increase in the formation of keratinized tissue, improving the probing depth parameters and the clinical attachment level, although it has not increased the degree of root coverage. ${ }^{93}$ 


\section{LOW-LEVEL LASERS IN PERIODONTICS}

\begin{tabular}{|c|c|c|c|c|c|}
\hline \multicolumn{6}{|c|}{ Photobiomodulation (PBM) Therapy } \\
\hline \multirow{2}{*}{\multicolumn{3}{|c|}{$\begin{array}{l}\text { Non-Surgical Periodontal Treatment } \\
\text { - adjunctive to scaling and root planing procedure (SRP) } \\
\text { - inflammation control } \\
\text { - reduction of edema, postoperative pain } \\
\text { - treatment of dentin hypersensitivity } \\
\text { - supporting the treatment of periodontitis in diabetic } \\
\text { patients }\end{array}$}} & \multicolumn{3}{|c|}{$\begin{array}{l}\text { Surgical Periodontal Treatment } \\
\text { - reduction of postoperative symptoms of periodontal surgery } \\
\text { - acceleration of tissue repair in the mediate or immediate postoperative } \\
\text { periodontal surgeries involving soft and bone tissue, associated or not with the } \\
\text { use of regenerative techniques }\end{array}$} \\
\hline & & & \multicolumn{2}{|c|}{ Reduction of Pain } & Bone Repair \\
\hline $\begin{array}{c}\text { ENERGY } \\
\text { DENSITY OR } \\
\text { ENERGY }\end{array}$ & 1 - $3 \mathrm{~J} / \mathrm{site}$ & $0.6-12 \mathrm{~J} /$ tooth & $\begin{array}{c}4.5 \mathrm{~J} \\
15-60 \mathrm{~J} / \mathrm{cm}^{2}\end{array}$ & $6-40 \mathrm{~J} / \mathrm{cm}^{2}$ & $4-10 \mathrm{~J} / \mathrm{cm}^{2}$ \\
\hline $\begin{array}{l}\text { NUMBER OF } \\
\text { SESSIONS }\end{array}$ & $3-4$ & $5-10$ & $3-8$ & $1-5$ & $3-10$ \\
\hline WAVELENGTH & $780-980 \mathrm{~nm}$ & $630-660 \mathrm{~nm}$ & $660 \mathrm{~nm}$ & $810-940 \mathrm{~nm}$ & $780-830 \mathrm{~nm}$ \\
\hline POWER & $70-400 \mathrm{~mW}$ & $25-200 \mathrm{~mW}$ & $20-30 \mathrm{~mW}$ & $100-500 \mathrm{~mW}$ & $30-100 \mathrm{~mW}$ \\
\hline
\end{tabular}

Figure 2. Indications and irradiation parameters of the low-level lasers (PBM) described in the periodontal studies.

\section{Antimicrobial photodynamic therapy (Figure 3)}

History of antimicrobial Photodynamic Therapy (APDT)

APDT refers to the use of light-absorbing chemicals together with electromagnetic radiation (usually visible light) in order to produce a microbial cell-killing or inactivating effect. Effective chemicals used here are known as photoantimicrobials, as they exert their effects against all classes of microbe, i.e. bacteria, viruses, fungi and protists. ${ }^{94}$ While photoantimicrobial plants (e.g. bloodroot, Sanguinaria spp) have been in existence for millions of years, the first reported in vitro demonstration was by Oskar Raab in 1900, when he observed the inactivation of the unicellular microorganism Paramecium caudatum using the synthetic dyes acridine phosphine and eosin along with white light. ${ }^{95}$

From Raab's discovery until around 1990 the reporting of in vitro APDT discoveries was sporadic, but the phenothiazinium dyes methylene blue and toluidine blue had by that time become the lead compounds for photoantimicrobial discovery and development, ${ }^{96}$ and the principal clinical indication was - and remains - oral infection. The essential requirement for light activation in APDT obviously suggests its use against local, easily-reached infections, although fibre optic technology allows access to deeper-seated, localised disease. A great deal of the basis for APDT against oral infection was carried out by Wilson and co-workers in the late 1980s/early 1990s, and in this period a wide range of relevant microbial pathogens had been shown to be susceptible to the approach. ${ }^{97}$

Another of the useful aspects of APDT is its efficacy regardless of the conventional drug resistance profile of the target organism. Given current global concerns over uncontrolled increases in conventional drug resistance, APDT using methylene blue therefore offers considerable potential in dentistry in the management of pathogens such as vancomycin-resistant enterococci. ${ }^{98}$ The antimicrobial, as opposed to antibacterial, potential of APDT also means that the applied photoantimicrobial would also be effective against fungal infection of the oral cavity, such as candidiasis. ${ }^{99}$

\section{Basic principles of APDT}

As noted above, APDT relies on the interaction of the photoantimicrobial substance with incident light of the correct wavelength. For methylene blue this means red light (methylene blue has an intense long-wavelength absorption at $660 \mathrm{~nm}$ ), and the 
absorption of this light energy allows the promotion of a ground state electron to a higher, excited state. In addition, the ground state electron, as part of a pair, has an opposite spin to its partner, so the ground state is referred to as a singlet and this is maintained in the excited state. However, while most colorants absorb light and undergo this process, the singlet excited state is normally deactivated rapidly by the electron returning to the ground state. Photosensitizers (including photoantimicrobials) represent a much smaller subset where the singlet excited state is relatively long-lived (microseconds) and this allows the spin of the electron to invert, so that it is the same as that of its original partner, but still excited, losing only a small amount of energy. This is the triplet state, and the fact that the spins are unpaired allows much easier electron transfer processes. Reaction of the triplet state compound with oxygen via electron transfer or transfer of the triplet energy direct to ground state oxygen produces highly reactive (highly oxidizing) chemicals called reactive oxygen species (ROS). The basis of APDT is the production of ROS either within or upon the microbial target.

Damage to the target cell depends on the localization of the photoantimicrobial. This is because the ROS are formed and subsequently react with biomolecules in close proximity. Consequently, photoantimicrobial localization at the cell exterior leads to external damage, for example to the Gram-positive bacterial cell wall, or the Gram-negative outer membrane. Conversely, internalized photoantimicrobials may, on illumination cause damage to cytoplasmic enzymes and/or DNA. Since photoantimicrobial localization can vary with concentration and incubation time, the ensuing biomolecular damage is variable. This variation means that it is difficult to envisage the development of drug resistance - i.e. multiple sites/modes of action require too many cellular changes in order to counteract them all at once.

\section{Photodynamic therapy on oral bacterial infections:} mechanism of action

Typical exemplar bacteria implicated in periodontic infection, Aggregatibacter actinomycetemcomitans, Porphyromonas gingivalis and Fusobacterium nucleatum can be combated using the photodynamic approach. ${ }^{100}$ This may seem surprising, given that each example is a Gram-negative species. The destruction of Aggregatibacter actinomycetemcomitans biofilms using photoactivated methylene blue has been reported, and this again demonstrates the range of biomolecular types sensitive to the effects of ROS.101 Similarly, the loss of virulence factor in A. actinomycetemcomitans has been demonstrated using indocyanine green-chitosan nanoparticles. ${ }^{102}$

In Porphyromonas gingivalis mainly outer membrane protein damage has been reported using the cationic (positively-charged) phenothiazinium photoantimicrobial toluidine blue, but little effect on bacterial (cytoplasmic) DNA, although at both sites the damage observed was accredited to singlet oxygen. ${ }^{103}$ The effects of the principal phenothiazine photoantimicrobial methylene blue against Fusobacterium nucleatum have not been reported in detail. However, the increased efficacy of added metronidazole, used as a combination approach post-illumination is suggestive of increased target cell permeability, presumably due again to outer membrane damage, as noted above. ${ }^{104}$

\section{Scientific evidences: animal studies}

Scientific evidence from experimental animal studies has demonstrated the effectiveness of APDT as monotherapy or as an adjunct in the treatment of experimental periodontitis. ${ }^{105}$ The potential of this therapy in modulating the local inflammatory response and in controlling bone resorption in sites with experimental periodontitis has be confirmed. Several studies have been developed to evaluate the effect of APDT on experimental periodontitis in animals (rats) with or without diseases or systemic changes..$^{70-73,106-111}$ In animals devoid of diseases or systemic changes, APDT has been shown to be effective in the treatment of experimentally induced periodontal disease, when used alone or as an adjunct to conventional mechanical treatment. ${ }^{69-73,106,109,110}$ The results of experimental studies have shown that APDT alone or as an adjuvant promotes control and reduction of alveolar bone loss, modulates the immune-inflammatory response, ${ }^{67-73,111}$ reduces pro-inflammatory cytokines ${ }^{69,110}$ and is capable of reducing periodontopathogenic microorganisms. ${ }^{110}$ 
Recent meta-analysis including studies in animals that evaluated the effect of APDT in the treatment of experimental induced disease including 9 articles concluded that the adjunctive use of APDT favors the reduction of alveolar bone loss in animals, and that results are more evident in systemically compromised animals..$^{105}$

Most of the studies described previously used phenothiazine photosensitizer, Methylene Blue (MB) or ortho-Toluidine Blue (TBO). We recently evaluated a photosensitizer that has shown great promise in reducing microorganisms: Toluidine Butyl Blue. ${ }^{111}$ The results demonstrated its effectiveness in promoting bone tissue remodeling in areas with experimental periodontitis, reducing the inflammatory process and accelerating bone neoformation, by increasing the migration and production of TGF- $\beta 1$ and Osteocalcin $(\mathrm{OCN})$, especially when used in the concentration of $0.5 \mathrm{mg} / \mathrm{ml}^{111}$

The effects of APDT over the control of alveolar bone loss might be due to its bactericidal activity against periodontopathogens. Our studies have showed that APDT modulates inflammatory response through reduction of expression of pro-inflammatory cytokines, ${ }^{110}$ consequently affecting RANKL/OPG system, leading to the reduction of bone loss. ${ }^{71,73,108}$ Hence, combined with its antimicrobial effects, APDT can also act over bone repair by accelerating the healing process through PBM mediated by LLL. ${ }^{70,71,73}$

\section{Scientific evidences: clinical studies in humans}

APDT has been clinically evaluated in several clinical studies as adjunctive therapy to the treatment of periodontitis. However, due to the diversity of protocols for the use of this therapy in studies, it is observed that the results are controversial and inconclusive. It should be noted that the clinical studies found in the literature have used different photosensitizers associated with lasers or LEDs with different wavelengths. In addition to the type and concentration of the photosensitizers, other parameters have been highly variable in APDT, such as the pre-irradiation time (between 1, 3 and 5 minutes), the power used (between 60 and $280 \mathrm{~mW}$ ), the exposure time (between 10 and 180 seconds/site), the number of sessions (single or multiple), frequency and interval between sessions.
Some clinical studies, despite not showing advantages in CAL level after using APDT, have shown that this therapy is capable of reducing bleeding and controlling inflammation of treated tissues. ${ }^{112-115}$ Others have shown that APDT was able to promote bacterial reduction, mainly of periodontopathogenic bacteria. ${ }^{116,117}$ There is some scientific evidence on the effects of multiple applications of APDT on periodontal treatment. ${ }^{114,115,117-19}$ One of these studies demonstrated that three applications of APDT (first, third and seventh days) promoted a greater reduction in Aggregatibacter actinomycetemcomitans, Tannerella forsythia and Treponema denticola in moderate pockets (4-6 mm), of Treponema denticola in deep pockets $(>6 \mathrm{~mm})$, and reduced bleeding on probing, when compared to isolated RAR. ${ }^{115}$ Our research group has demonstrated that a protocol of three APDT sessions (Methylene Blue, $660 \mathrm{~nm}, 160 \mathrm{~J} / \mathrm{cm}^{2}$ ) with an interval of 48 hours and pre-irradiation time of 1 minute in moderate and deep pockets proved to be clinically effective as much as systemic antibiotic therapy, as an adjunct therapy in the treatment of chronic periodontitis in both non-smoking patients ${ }^{118}$ and in smokers. ${ }^{117}$

Randomized controlled clinical study compared the effect of this APDT protocol (three weekly applications) as an adjunct to the treatment of periodontitis in non-compensated diabetic patients. ${ }^{119}$ APDT as an adjunctive therapy has clinically benefited patients, as it was able to reduce the number of pockets with probing depth $\geq 5 \mathrm{~mm}$ with bleeding at 90 and 180 days, in addition to reducing the average probing depth of deep pockets at 180 days after the treatment. In the treatment of residual pockets in maintenance, studies have shown advantages of using APDT, either as an alternative therapy or as an adjunct to periodontal treatment. ${ }^{120-123}$ Clinical evidence has shown that APDT promotes clinical benefits in reducing inflammation of periodontal tissues, reducing residual pockets and gaining of CAL as maintenance therapy. ${ }^{120-122}$ Several sessions of APDT as adjunctive therapy for the treatment of residual pockets in maintenance therapy have shown to be effective (five applications over a two-week period). ${ }^{120}$ Another clinical study, which employed APDT as an alternative therapy, using MB $(10 \mathrm{mg} / \mathrm{mL})$, pre-irradiation time of 1 minute and irradiation with diode laser $(660 \mathrm{~nm})$ 
for 1 minute, positioning the fiber inside the pocket, demonstrated clinical benefits in the treatment of residual pockets for promoting modulation of crevicular fluid cytokines. ${ }^{122}$ However, a clinical study evaluating APDT in maintenance therapy as an adjunct to periodontal treatment employing $\mathrm{MB}$ $(0.01 \%)$, pre-irradiation of 5 minutes, $90 \mathrm{~s}$ of treatment with DL $(660 \mathrm{~nm})$, concluded that this procedure failed to demonstrate clinical and bacteriological benefits. ${ }^{124}$ Other study of our team showed that the treatment of residual pockets in patients with type 2 Diabetes Mellitus through association of SRP with APDT (curcumin solution $100 \mathrm{mg} / \mathrm{L}$ and LED irradiation) or LED irradiation may yield short-term clinical benefits regarding CAL gain. ${ }^{125}$

Systematic reviews and meta-analysis studies have shown controversial results on APDT in periodontics, and the level of certainty of these reviews varies from very low to moderate. ${ }^{12,126-134}$ Regarding the initial treatment of aggressive or chronic periodontitis, some reviews showed encouraging results with several applications, including in the short term, ${ }^{126-129}$ while others did not confirm superior effectiveness to conventional treatment or that its effect is limited..$^{12,130-132}$ Regarding the use of APDT in diabetics ${ }^{133}$ or smokers, ${ }^{134}$ there is still a lack of studies. A meta-analysis of our team compared APDT to systemic antibiotic therapy with amoxicillin plus metronidazole on the non-surgical treatment of periodontitis. ${ }^{135}$ Although it was observed a limited number of randomized controlled clinical studies (4) and great heterogeneity between them, it was concluded that APDT presents similar clinical results compared to antibiotic therapy as adjuvants in the non-surgical treatment of periodontitis. ${ }^{135}$

\section{Conclusions}

In nonsurgical periodontal therapy there is an additional clinical benefit when using DL

\section{LOW-LEVEL LASERS IN PERIODONTICS}

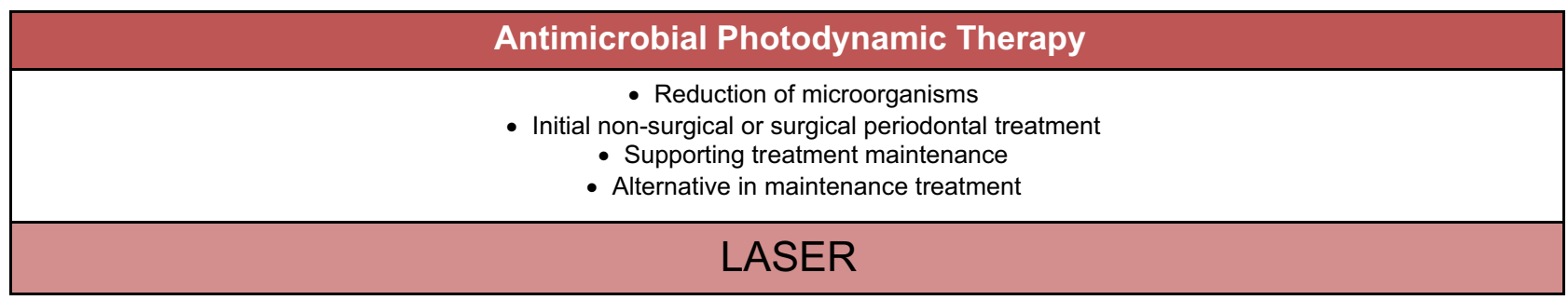

\begin{tabular}{|c|c|c|c|c|}
\hline & \multicolumn{2}{|c|}{ Initial Therapy } & \multicolumn{2}{|c|}{ Maintenance Therapy } \\
\hline & SINGLE SESSION & MULTIPLE SESSIONS & SINGLE SESSION & MULTIPLE SESSIONS \\
\hline $\begin{array}{l}\text { ENERGY DENSITY } \\
\text { OR ENERGY }\end{array}$ & $16-129 \mathrm{~J} / \mathrm{cm}^{2}$ & $16-160 \mathrm{~J} / \mathrm{cm}^{2}$ & & $\begin{array}{c}2.49 \text { (site) }-14.94 \text { (tooth) } \\
\mathrm{J} / \mathrm{cm}^{2}\end{array}$ \\
\hline $\begin{array}{c}\text { TIME OF } \\
\text { IRRADIATION }\end{array}$ & $10-150$ seconds & $10-180$ seconds & 10 - 60 seconds & $60-120$ seconds \\
\hline WAVELENGTH & $635-690 \mathrm{~nm}$ & $660-670 \mathrm{~nm}$ & $660-670 \mathrm{~nm}$ & $660-670 \mathrm{~nm}$ \\
\hline PHOTOSENSITIZER & $\mathrm{MB}$ and TBO & $\mathrm{MB}$ and TBO & $\mathrm{MB}$ & MB \\
\hline $\begin{array}{l}\text { NUMBER OF } \\
\text { SESSIONS }\end{array}$ & 1 & $3-4$ & 1 & $2-5$ \\
\hline $\begin{array}{c}\text { PRE-IRRADIATION } \\
\text { TIME } \\
\end{array}$ & $10-300$ seconds & $60-300$ seconds & 60 seconds & 60 seconds \\
\hline POWER & $60-150 \mathrm{~mW}$ & $75-100 \mathrm{~mW}$ & $75 \mathrm{~mW}$ & $75-280 \mathrm{~mW}$ \\
\hline
\end{tabular}

MB: Methylene Blve; TBO: Toluidine Blue-O.

Figure 3. Indications and irradiation parameters of the low-level lasers in APDT described in the periodontal studies. 
associated with SRP in patients with moderate to severe periodontitis. Er:YAG laser promotes the same clinical effects as conventional SRP therapy. Periodontal surgery of the gingival or mucosal tissue and granulation tissue can be carried out with DL, $\mathrm{CO}_{2}$, Nd:YAG, Er:YAG and Er,Cr:YSGG. The osteotomy using Er:YAG or Er,Cr:YSGG proved to be a safe and precise procedure.

Based on the analysis of data found in the literature, it can be observed that PBM mediated by LLL is effective in controlling inflammation, in accelerating the biological events of tissue repair and in reducing pain in both non-surgical and surgical therapy, with highlighted results in the short term. It should be noted that PBM modulates the host's tissue response from the deposition in the treated area of light photons. When absorbing the light, cells that have their energy gradient changed, due to injury or systemic modifications, will have their energy recomposition and consequently their biological mechanisms will be activated. In this case, the photonic effect is evident after several sessions. For this reason, in many cases, a single application does not express results as satisfactory as multiple sessions with PBM.
The fact that the effects of APDT mediated by LLL are relevant in the initial reevaluation periods is not surprising, but very obvious, considering that the photonic effects of this therapy last only as long as there is irradiation of the tissues by the light source and in the presence of the photosensitizer, when reactive oxygen species are formed. This evidence should neither be considered low, nor as a disadvantage or reason for contraindication of this therapy. In fact, it has numerous advantages when compared to other adjutant therapies, such as the possibility of use in various applications, its low cost, absence of side effects and formation of resistant bacterial strains.

However, instead of several clinical studies showed clinical beneficial effects of several lasers in periodontal treatment, there are low clinical scientific evidences that showed additional advantages of lasers as adjunctive treatment in periodontology. In addition, most systematic reviews showed the level of certainty as low to moderate. Studies have shown controversial results of use of lasers in periodontics, and this fact may be to the lack of standard parameters of irradiation in each clinical application, and low level of knowledge of basic principles of photonic therapies by the professional.

\section{References}

1. Pick RM, Pecaro BC, Silberman CJ. The laser gingivectomy. The use of the CO2 laser for the removal of phenytoin hyperplasia. J Periodontol. 1985 Aug;56(8):492-6. https://doi.org/10.1902/jop.1985.56.8.492

2. Theodoro LH, Garcia VG. Uso do laser e suas implicações como alternativa terapêutica na Periodontia e Implantodontia. In: Silva EB, Grisi DC. Periodontia no contexto interdisciplinar integrando as melhores práticas. Nova Odessa: Napoleão; 2015. p. 352-7.

3. Theodoro LH, Garcia VG. Surgical and non-surgical treatment of periodontal diseases. In: Freitas PM, Simões A, editors. Lasers in dentistry: guide for clinical practice. New Jersey: Wiley Blackwell; 2015. p. 153-8.

4. Israel M, Cobb CM, Rossmann JA, Spencer P. The effects of CO2, Nd:YAG and Er:YAG lasers with and without surface coolant on tooth root surfaces: an in vitro study. J Clin Periodontol. 1997 Sep;24(9 Pt 1):595-602. https://doi.org/10.1111/j.1600-051X.1997.tb00235.x

5. Theodoro LH, Haypek P, Bachmann L, Garcia VG, Sampaio JE, Zezell DM, et al. Effect of ER:YAG and diode laser irradiation on the root surface: morphological and thermal analysis. J Periodontol. 2003 Jun;74(6):838-43. https://doi.org/10.1902/jop.2003.74.6.838

6. Theodoro LH, Sampaio JE, Haypek P, Bachmann L, Zezell DM, Garcia VG. Effect of Er:YAG and Diode lasers on the adhesion of blood components and on the morphology of irradiated root surfaces. J Periodontal Res. 2006 Oct;41(5):381-90. https://doi.org/10.1111/j.1600-0765.2005.00846.x

7. Ting CC, Fukuda M, Watanabe T, Aoki T, Sanaoka A, Noguchi T. Effects of Er,Cr:YSGG laser irradiation on the root surface: morphologic analysis and efficiency of calculus removal. J Periodontol. 2007 Nov;78(11):2156-64. https://doi.org/10.1902/jop.2007.070160

8. Oliveira GJ, Pavone C, Sampaio JE, Marcantonio RA. Influence of the angle of irradiation of the Er,Cr:YSGG laser on the morphology, attachment of blood components, roughness, and root wear: in vitro study. Lasers Surg Med. feist2010;42(9):683-691. https://doi.org/10.1002/Ism.20973

9. Hosseinipour ZS, Pirmoradian-Najafabadi M, Shahabi S. Relationship between Er,Cr:YSGG laser power and surface roughness of lased radicular dentin. J Dent Res Dent Clin Dent Prospects. 2018 Jun;12(2):83-90. https://doi.org/10.15171/joddd.2018.013 
10. Hamblin MR. Mechanisms and applications of the anti-inflammatory effects of photobiomodulation. AIMS Biophys. 2017;4(3):337-61. https://doi.org/10.3934/biophy.2017.3.337

11. Chambrone L, Ramos UD, Reynolds MA. Infrared lasers for the treatment of moderate to severe periodontitis: an American Academy of Periodontology best evidence review. J Periodontol. 2018 Jul;89(7):743-65. https://doi.org/10.1902/jop.2017.160504

12. Salvi GE, Stähli A, Schmidt JC, Ramseier CA, Sculean A, Walter C. Adjunctive laser or antimicrobial photodynamic therapy to non-surgical mechanical instrumentation in patients with untreated periodontitis: a systematic review and meta-analysis. J Clin Periodontol. 2020 Jul;47(S22 Suppl 22):176-98. https://doi.org/10.1111/icpe.13236

13. Sanz M, Herrera D, Kebschull M, Chapple I, Jepsen S, Beglundh T, et al. Treatment of stage I-III periodontitis: the EFP S3 level clinical practice guideline. J Clin Periodontol. 2020 Jul;47(S22 Suppl 22):4-60. https://doi.org/10.1111/icpe.13290

14. Theodoro LH, Garcia VG, Ervolino E. Aplicações Clínicas dos Lasers de Alta Potência em Periodontia. In: Garcia VG, Theodoro LH, editors. Laser em Odontologia: uma visão clínica baseada em evidências científicas. 1st ed. São Paulo: Santos Publicações; 2021.

15. Slot DE, Kranendonk AA, Paraskevas S, Van der Weijden F. The effect of a pulsed Nd:YAG laser in non-surgical periodontal therapy. J Periodontol. 2009 Jul;80(7):1041-56. https://doi.org/10.1902/jop.2009.080571

16. Nguyen NT, Byarlay MR, Reinhardt RA, Marx DB, Meinberg TA, Kaldahl WB. Adjunctive non-surgical therapy of inflamed periodontal pockets during maintenance therapy using diode laser: a randomized clinical trial. J Periodontol. 2015 Oct;86(10):1133-40. https://doi.org/10.1902/jop.2015.150152

17. Sağlam M, Köseoğlu S, Taşdemir I, Erbak Yılmaz H, Savran L, Sütçü R. Combined application of Er:YAG and Nd:YAG lasers in treatment of chronic periodontitis. A split-mouth, single-blind, randomized controlled trial. J Periodontal Res. 2017 Oct;52(5):853-62. https://doi.org/10.1111/jre.12454

18. Grzech-Leśniak K, Sculean A, Gašpirc B. Laser reduction of specific microorganisms in the periodontal pocket using Er:YAG and Nd:YAG lasers: a randomized controlled clinical study. Lasers Med Sci. 2018 Sep;33(7):1461-70. https://doi.org/10.1007/s10103-018-2491-z

19. Zezell DM, Ana PA. High power lasers and their interaction with biological tissues. In: Freitas PM, Simões A, editors. Lasers in dentistry, guide for clinical practice. New Jersey: Wiley Blackwell; 2015. https://doi.org/10.1002/9781118987742.ch2

20. Caruso U, Nastri L, Piccolomini R, Ercole S, Mazza C, Guida L. Use of diode laser $980 \mathrm{~nm}$ as adjunctive therapy in the treatment of chronic periodontitis. A randomized controlled clinical trial. New Microbiol. 2008 Oct;31(4):513-8.

21. Kamma JJ, Vasdekis VG, Romanos GE. The effect of diode laser $(980 \mathrm{~nm})$ treatment on aggressive periodontitis: evaluation of microbial and clinical parameters. Photomed Laser Surg. 2009 Feb;27(1):11-9. https://doi.org/10.1089/pho.2007.2233

22. De Micheli G, Andrade AK, Alves VT, Seto M, Pannuti CM, Cai S. Efficacy of high intensity diode laser as an adjunct to non-surgical periodontal treatment: a randomized controlled trial. Lasers Med Sci. 2011 Jan;26(1):43-8. https://doi.org/10.1007/s10103-009-0753-5

23. Giannelli M, Bani D, Viti C, Tani A, Lorenzini L, Zecchi-Orlandini S, et al. Comparative evaluation of the effects of different photoablative laser irradiation protocols on the gingiva of periodontopathic patients. Photomed Laser Surg. 2012 Apr;30(4):222-30. https://doi.org/10.1089/pho.2011.3172

24. Alves VTE, Andrade AK, Toaliar JM, Conde MC, Zezell DM, Cai S, et al. Clinical and microbiological evaluation of high intensity diode laser adjutant to non-surgical periodontal treatment: a 6-month clinical trial. Clin Oral Investig. 2013 Jan;17(1):87-95. https://doi.org/10.1007/s00784-012-0703-7

25. Gojkov-Vukelic M, Hadzic S, Dedic A, Konjhodzic R, Beslagic E. Application of a diode laser in the reduction of targeted periodontal pathogens. Acta Inform Med. 2013 Dec;21(4):237-40. https://doi.org/10.5455/aim.2013.21.237-240

26. Theodoro LH, Caiado RC, Longo M, Novaes VC, Zanini NA, Ervolino E, et al. Effectiveness of the diode laser in the treatment of ligature-induced periodontitis in rats: a histopathological, histometric, and immunohistochemical study. Lasers Med Sci. 2015 May;30(4):1209-18. https://doi.org/10.1007/s10103-014-1575-7

27. Qadri T, Javed F, Johannsen G, Gustafsson A. Role of diode lasers $(800-980 \mathrm{~nm})$ as adjuncts to scaling and root planing in the treatment of chronic periodontitis: a systematic review. Photomed Laser Surg. 2015 Nov;33(11):568-75. https://doi.org/10.1089/pho.2015.3914

28. Chandra S, Shashikumar P. Diode Laser: a novel therapeutic approach in the treatment of chronic periodontitis in Type 2 Diabetes Mellitus patients: a prospective randomized controlled clinical trial. J Lasers Med Sci. 2019;10(1):56-63. https://doi.org/10.15171/jlms.2019.09

29. Jia L, Jia J, Xie M, Zhang X, Li T, Shi L, et al. Clinical attachment level gain of lasers in scaling and root planing of chronic periodontitis: a network meta-analysis of randomized controlled clinical trials. Lasers Med Sci. 2020 Mar;35(2):473-85. https://doi.org/10.1007/s10103-019-02875-5

30. Theodoro LH, Garcia VG, Haypek P, Zezell DM, Eduardo CP. Morphologic analysis, by means of scanning electron microscopy, of the effect of Er: YAG laser on root surfaces submitted to scaling and root planing. Pesqui Odontol Bras. 2002 Oct-Dec;16(4):308-12. https://doi.org/10.1590/S1517-74912002000400005

31. Oliveira GJ, Theodoro LH, Marcantonio Junior E, Sampaio JE, Marcantonio RA. Effect of Er,Cr:YSGG and Er:YAG laser irradiation on the adhesion of blood components on the root surface and on root morphology. Braz Oral Res. 2012 May-Jun;26(3):256-62. https://doi.org/10.1590/S1806-83242012000300012 
32. Theodoro LH, Zezell DM, Garcia VG, Haypek P, Nagata MJ, Almeida JM, et al. Comparative analysis of root surface smear layer removal by different etching modalities or erbium:yttrium-aluminum-garnet laser irradiation: a scanning electron microscopy study. Lasers Med Sci. 2010 Jul;25(4):485-91. https://doi.org/10.1007/s10103-009-0665-4

33. Feist IS, De Micheli G, Carneiro SR, Eduardo CP, Miyagi S, Marques MM. Adhesion and growth of cultured human gingival fibroblasts on periodontally involved root surfaces treated by Er:YAG laser. J Periodontol. 2003 Sep;74(9):1368-75. https://doi.org/10.1902/jop.2003.74.9.1368

34. Agoob Alfergany M, Nasher R, Gutknecht N. Calculus removal and root surface roughness when using the Er:YAG or Er, Cr:YSGG Laser compared with conventional instrumentation method: a literature review. Photobiomodul Photomed Laser Surg. 2019 Apr;37(4):197-226. https://doi.org/10.1089/photob.2018.4465

35. Schwarz F, Sculean A, Georg T, Reich E. Periodontal treatment with an Er: YAG laser compared to scaling and root planing: a controlled clinical study. J Periodontol. 2001 Mar;72(3):361-7. https://doi.org/10.1902/jop.2001.72.3.361

36. Schwarz F, Sculean A, Berakdar M, Georg T, Reich E, Becker J. Clinical evaluation of an Er:YAG laser combined with scaling and root planing for non-surgical periodontal treatmen: a controlled, prospective clinical study. J Clin Periodontol. 2003 Jan;30(1):26-34. https://doi.org/10.1034/i.1600-051X.2003.300105.x

37. Schwarz F, Sculean A, Berakdar M, Georg T, Reich E, Becker J. Periodontal treatment with an Er:YAG laser or scaling and root planing: a 2-year follow-up split-mouth study. J Periodontol. 2003 May;74(5):590-6. https://doi.org/10.1902/jop.2003.74.5.590

38. Tomasi C, Schander K, Dahlén G, Wennström JL. Short-term clinical and microbiologic effects of pocket debridement with an Er:YAG laser during periodontal maintenance. J Periodontol. 2006 Jan;77(1):111-8. https://doi.org/10.1902/jop.2006.77.1.111

39. Lopes BM, Marcantonio RA, Thompson GM, Neves LH, Theodoro LH. Short-term clinical and immunologic effects of scaling and root planing with Er:YAG laser in chronic periodontitis. J Periodontol. 2008 Jul;79(7):1158-67. https://doi.org/10.1902/jop.2008.070600

40. Lopes BM, Theodoro LH, Melo RF, Thompson GM, Marcantonio RA. Clinical and microbiologic follow-up evaluations after non-surgical periodontal treatment with erbium:YAG laser and scaling and root planing. J Periodontol. 2010 May;81(5):682-91. https://doi.org/10.1902/jop.2010.090300

41. Zengin Celik T, Saglam E, Ercan C, Akbas F, Nazaroglu K, Tunali M. Clinical and microbiological effects of the use of erbium: yttrium-aluminum-garnet laser on chronic periodontitis in addition to nonsurgical periodontal treatment: a randomized clinical trial-6 months follow-up. Photobiomodul Photomed Laser Surg. 2019 Mar;37(3):182-90. https://doi.org/10.1089/photob.2018.4510

42. Klepper KL, Chun YP, Cochran D, Chen S, McGuff HS, Mealey BL. Impact of Er:YAG laser on wound healing following nonsurgical therapy: A pilot study. Clin Exp Dent Res. 2019 Apr;5(3):250-8. https://doi.org/10.1002/cre2.179

43. Ma L, Zhang X, Ma Z, Shi H, Zhang Y, Wu M, et al. Clinical effectiveness of Er: YAG Lasers adjunct to scaling and root planing in non-surgical treatment of chronic periodontitis: a meta-analysis of randomized controlled trials. Med Sci Monit. 2018 Oct;24:7090-9. https://doi.org/10.12659/MSM.911863

44. Sezen D, Hatipoğlu M, Üstün K. Evaluation of the clinical and biochemical efficacy of erbium, chromium:ytrium-scandium-gallium-garnet (ER,CR:YSGG) laser treatment in periodontitis. Lasers Med Sci. 2020 Sep;35(7):1567-75. https://doi.org/10.1007/s10103-020-02990-8

45. Hakki SS, Berk G, Dundar N, Saglam M, Berk N. Effects of root planing procedures with hand instrument or erbium, chromium:yttriumscandium-gallium-garnet laser irradiation on the root surfaces: a comparative scanning electron microscopy study. Lasers Med Sci. 2010 May;25(3):345-53. https://doi.org/10.1007/s10103-009-0643-x

46. Kelbauskiene S, Maciulskiene V. A pilot study of $\mathrm{Er}, \mathrm{Cr}$ :YSGG laser therapy used as an adjunct to scaling and root planing in patients with early and moderate periodontitis. Stomatologija. 2007;9(1):21-6.

47. Kelbauskiene S, Baseviciene N, Goharkhay K, Moritz A, Machiulskiene V. One-year clinical results of Er,Cr:YSGG laser application in addition to scaling and root planing in patients with early to moderate periodontitis. Lasers Med Sci. 2011 Jul;26(4):44552. https://doi.org/10.1007/s10103-010-0799-4

48. Dyer B, Sung EC. Minimally invasive periodontal treatment using the $\mathrm{Er}, \mathrm{Cr}$ :YSGG laser: a 2-year retrospective preliminary clinical study. Open Dent J. 2012;6(1):74-8. https://doi.org/10.2174/1874210601206010074

49. Gupta M, Lamba AK, Verma M, Faraz F, Tandon S, Chawla K, et al. Comparison of periodontal open flap debridement versus closed debridement with Er,Cr:YSGG laser. Aust Dent J. 2013 Mar;58(1):41-9. https://doi.org/10.1111/adj.12021

50. Ciurescu CE, Cosgarea R, Ciurescu D, Gheorghiu A, Popa D, Franzen R, et al. Adjunctive use of InGaAsP and Er, Cr:YSGG lasers in nonsurgical periodontal therapy: a randomized controlled clinical study. Quintessence Int. 2019;50(6):436-47. https://doi.org/10.3290/i.qi.a42508

51. Ge L, Zhang Y, Shu R. Er,Cr:YSGG Laser application for the treatment of periodontal furcation involvements. Photomed Laser Surg. 2017 Feb;35(2):92-7. https://doi.org/10.1089/pho.2016.4145

52. Taniguchi Y, Aoki A, Sakai K, Mizutani K, Meinzer W, Izumi Y. A novel surgical procedure for Er:YAG laser-assisted periodontal regenerative therapy: case series. Int J Periodontics Restorative Dent. 2016 Jul-Aug;36(4):507-15. https://doi.org/10.11607/prd.2515

53. Mizutani K, Aoki A, Coluzzi D, Yukna R, Wang CY, Pavlic V, et al. Lasers in minimally invasive periodontal and peri-implant therapy. Periodontol 2000. 2016 Jun;71(1):185-212. https://doi.org/10.1111/prd.12123 
54. Gokhale SR, Padhye AM, Byakod G, Jain SA, Padbidri V, Shivaswamy S. A comparative evaluation of the efficacy of diode laser as an adjunct to mechanical debridement versus conventional mechanical debridement in periodontal flap surgery: a clinical and microbiological study. Photomed Laser Surg. 2012 Oct;30(10):598-603. https://doi.org/10.1089/pho.2012.3252

55. Behdin S, Monje A, Lin GH, Edwards B, Othman A, Wang HL. Effectiveness of laser application for periodontal surgical therapy: systematic review and meta-analysis. J Periodontol. 2015 Dec;86(12):1352-63. https://doi.org/10.1902/jop.2015.150212

56. Wang $X$, Zhang $C$, Matsumoto K. In vivo study of the healing processes that occur in the jaws of rabbits following perforation by an Er,Cr:YSGG laser. Lasers Med Sci. 2005;20(1):21-7. https://doi.org/10.1007/s10103-005-0329-y

57. Perussi LR, Pavone C, Oliveira GJ, Cerri PS, Marcantonio RA. Effects of the Er,Cr:YSGG laser on bone and soft tissue in a rat model. Lasers Med Sci. 2012 Jan;27(1):95-102. https://doi.org/10.1007/s10103-011-0920-3

58. Theodoro LH, Garcia VG, Ervolino E. Lasers no tratamento da doença periodontal. In: Garcia VG, Theodoro LH, editors. Laser em Odontologia: uma visão clínica baseada em evidências científicas. São Paulo: Santos; 2021.

59. Ren C, McGrath C, Jin L, Zhang C, Yang Y. The effectiveness of low-level laser therapy as an adjunct to non-surgical periodontal treatment: a meta-analysis. J Periodontal Res. 2017 Feb;52(1):8-20. https://doi.org/10.1111/jre.12361

60. Stein S, Schauseil M, Hellak A, Korbmacher-Steiner H, Braun A. Influence of Photobiomodulation Therapy on Gingivitis Induced by Multi-Bracket Appliances: A Split-Mouth Randomized Controlled Trial. Photomed Laser Surg. 2018 Aug;36(8):399-405. https://doi.org/10.1089/pho.2017.4404

61. Qadri T, Miranda L, Tunér J, Gustafsson A. The short-term effects of low-level lasers as adjunct therapy in the treatment of periodontal inflammation. J Clin Periodontol. 2005 Jul;32(7):714-9. https://doi.org/10.1111/i.1600-051X.2005.00749.x

62. Aykol G, Baser U, Maden I, Kazak Z, Onan U, Tanrikulu-Kucuk S, et al. The effect of low-level laser therapy as an adjunct to non-surgical periodontal treatment. J Periodontol. 2011 Mar;82(3):481-8. https://doi.org/10.1902/jop.2010.100195

63. Obradović R, Kesić L, Mihailović D, Jovanović G, Antić S, Brkić Z. Low-level lasers as an adjunct in periodontal therapy in patients with diabetes mellitus. Diabetes Technol Ther. 2012 Sep;14(9):799-803. https://doi.org/10.1089/dia.2012.0027

64. Petrović MS, Kannosh IY, Milašin JM, Mihailović DS, Obradović RR, Bubani SR, et al. Clinical, microbiological and cytomorphometric evaluation of low-level laser therapy as an adjunct to periodontal therapy in patients with chronic periodontitis. Int J Dent Hyg. 2018 May;16(2):e120-7. https://doi.org/10.1111/idh.12328

65. Cobb CM. Lasers and the treatment of periodontitis: the essence and the noise. Periodontol 2000. 2017 Oct;75(1):205-95. https://doi.org/10.1111/prd.12137

66. Mokeem S. Efficacy of adjunctive low-level laser therapy in the treatment of aggressive periodontitis: A systematic review. J Investig Clin Dent. 2018 Nov;9(4):e12361. https://doi.org/10.1111/jicd.12361

67. Garcia VG, Fernandes LA, Almeida JM, Bosco AF, Nagata MJ, Martins TM, et al. Comparison between laser therapy and non-surgical therapy for periodontitis in rats treated with dexamethasone. Lasers Med Sci. 2010 Mar;25(2):197-206. https://doi.org/10.1007/s10103-009-0678-z

68. Theodoro LH, Longo M, Ervolino E, Duque C, Ferro-Alves ML, Assem NZ, et al. Effect of low-level laser therapy as an adjuvant in the treatment of periodontitis induced in rats subjected to 5-fluorouracil chemotherapy. J Periodontal Res. 2016 Oct;51(5):669-80. https://doi.org/10.1111/jre.12347

69. Theodoro LH, Longo M, Novaes VC, Miessi DM, Ferro-Alves ML, Ervolino E, et al. Low-level laser and antimicrobial photodynamic therapy on experimental periodontitis in rats submitted to chemotherapy by 5-fluorouracil. Support Care Cancer. 2017 Oct;25(10):326171. https://doi.org/10.1007/s00520-017-3738-0

70. Garcia VG, Fernandes LA, Macarini VC, de Almeida JM, Martins TM, Bosco AF, et al. Treatment of experimental periodontal disease with antimicrobial photodynamic therapy in nicotine-modified rats. J Clin Periodontol. 2011 Dec;38(12):1106-14. https://doi.org/10.1111/j.1600-051X.2011.01785.x

71. Gualberto Junior EC, Theodoro LH, Longo M, Novaes VC, Nagata MJ, Ervolino E, et al. Antimicrobial photodynamic therapy minimizes the deleterious effect of nicotine in female rats with induced periodontitis. Lasers Med Sci. 2016 Jan;31(1):83-94. https://doi.org/10.1007/s10103-015-1820-8

72. Garcia VG, Gualberto Júnior EC, Fernandes LA, Bosco AF, Hitomi Nagata MJ, Casatti CA, et al. Adjunctive antimicrobial photodynamic treatment of experimentally induced periodontitis in rats with ovariectomy. J Periodontol. 2013 Apr;84(4):556-65. https://doi.org/10.1902/jop.2012.120163

73. Garcia VG, Gualberto EC, Ervolino E, Nagata MJ, Almeida JM, Theodoro LH. aPDT for periodontitis treatment in ovariectomized rats under systemic nicotine. Photodiagn Photodyn Ther. 2018 Jun;22:70-8. https://doi.org/10.1016/i.pdpdt.2018.02.017

74. Angelov N, Pesevska S, Nakova M, Gjorgoski I, Ivanovski K, Angelova D, et al. Periodontal treatment with a low-level diode laser: clinical findings. Gen Dent. 2009 Sep-Oct;57(5):510-3.

75. Lai SM, Zee KY, Lai MK, Corbet EF. Clinical and radiographic investigation of the adjunctive effects of a low-power He-Ne laser in the treatment of moderate to advanced periodontal disease: a pilot study. Photomed Laser Surg. 2009 Apr;27(2):287-93. https://doi.org/10.1089/pho.2007.2206 
76. Makhlouf M, Dahaba MM, Tunér J, Eissa SA, Harhash TA. Effect of adjunctive low level laser therapy (LLLT) on nonsurgical treatment of chronic periodontitis. Photomed Laser Surg. 2012 Mar;30(3):160-6. https://doi.org/10.1089/pho.2011.3069

77. Calderín S, García-Núñez JA, Gómez C. Short-term clinical and osteoimmunological effects of scaling and root planing complemented by simple or repeated laser phototherapy in chronic periodontitis. Lasers Med Sci. 2013 Jan;28(1):157-66. https://doi.org/10.1007/s10103-012-1104-5

78. Pamuk F, Lütfioğlu M, Aydoğdu A, Koyuncuoglu CZ, Cifcibasi E, Badur OS. The effect of low-level laser therapy as an adjunct to non-surgical periodontal treatment on gingival crevicular fluid levels of transforming growth factor-beta 1, tissue plasminogen activator and plasminogen activator inhibitor 1 in smoking and non-smoking chronic periodontitis patients: a split-mouth, randomized control study. J Periodontal Res. 2017 Oct;52(5):872-82. https://doi.org/10.1111/ire.12457

79. Santos NC, Andere NM, Miguel MM, Santos LM, Santamaria M Jr, Mathias IF, et al. Photobiomodulation for the treatment of periodontal pockets in patients with type 2 diabetes: 1-year results of a randomized clinical trial. Lasers Med Sci. 2019 Dec;34(9):1897-904. https://doi.org/10.1007/s10103-019-02799-0

80. Özberk SS, Gündoğar H, Özkaya M, Taner IL, Erciyas K. The effect of photobiomodulation therapy on nonsurgical periodontal treatment in patients with type 2 diabetes mellitus: a randomized controlled, single-blind, split-mouth clinical trial. Lasers Med Sci. 2020 Mar;35(2):497-504. https://doi.org/10.1007/s10103-019-02897-z

81. Angiero F, Ugolini A, Cattoni F, Bova F, Blasi S, Gallo F, et al. Evaluation of bradykinin, VEGF, and EGF biomarkers in gingival crevicular fluid and comparison of PhotoBioModulation with conventional techniques in periodontitis: a split-mouth randomized clinical trial. Lasers Med Sci. 2020 Jun;35(4):965-70. https://doi.org/10.1007/s10103-019-02919-w

82. Woodruff LD, Bounkeo JM, Brannon WM, Dawes KS, Barham CD, Waddell DL, et al. The efficacy of laser therapy in wound repair: a meta-analysis of the literature. Photomed Laser Surg. 2004 Jun;22(3):241-7. https://doi.org/10.1089/1549541041438623

83. Garcia VG, Macarini VC, Almeida JM, Bosco AF, Nagata MJ, Okamoto T, et al. Influence of low-level laser therapy on wound healing in nicotine-treated animals. Lasers Med Sci. 2012 Mar;27(2):437-43. https://doi.org/10.1007/s10103-011-0956-4

84. Suzuki R, Takakuda K. Wound healing efficacy of a 660-nm diode laser in a rat incisional wound model. Lasers Med Sci. 2016 Nov;31(8):1683-9. https://doi.org/10.1007/s10103-016-2038-0

85. Ozcelik O, Cenk Haytac M, Kunin A, Seydaoglu G. Improved wound healing by low-level laser irradiation after gingivectomy operations: a controlled clinical pilot study. J Clin Periodontol. 2008 Mar;35(3):250-4. https://doi.org/10.1111/j.1600-051X.2007.01194.x

86. Zhao H, Hu J, Zhao L. The effect of low-level laser therapy as an adjunct to periodontal surgery in the management of postoperative pain and wound healing: a systematic review and meta-analysis. Lasers Med Sci. 2021;36(1):175-87. https://doi.org/10.1007/s10103-020-03072-5

87. Pessoa ES, Melhado RM, Theodoro LH, Garcia VG. A histologic assessment of the influence of low-intensity laser therapy on wound healing in steroid-treated animals. Photomed Laser Surg. 2004 Jun;22(3):199-204. https://doi.org/10.1089/1549541041438533

88. Eissa M, Salih WH. The influence of low-intensity He-Ne laser on the wound healing in diabetic rats. Lasers Med Sci. 2017 Aug;32(6):1261-7. https://doi.org/10.1007/s10103-017-2230-x

89. Heidari M, Fekrazad R, Sobouti F, Moharrami M, Azizi S, Nokhbatolfoghahaei H, et al. Evaluating the effect of photobiomodulation with a 940-nm diode laser on post-operative pain in periodontal flap surgery. Lasers Med Sci. 2018 Nov;33(8):1639-45. https://doi.org/10.1007/s10103-018-2492-y

90. AboElsaad NS, Soory M, Gadalla LM, Ragab LI, Dunne S, Zalata KR, et al. Effect of soft laser and bioactive glass on bone regeneration in the treatment of infra-bony defects (a clinical study). Lasers Med Sci. 2009 May;24(3):387-95. https://doi.org/10.1007/s10103-008-0576-9

91. Garcia VG, Conceição JM, Fernandes LA, Almeida JM, Nagata MJ, Bosco AF, et al. Effects of LLLT in combination with bisphosphonate on bone healing in critical size defects: a histological and histometric study in rat calvaria. Lasers Med Sci. 2013 Feb;28(2):407-14. https://doi.org/10.1007/s10103-012-1068-5

92. Garcia VG, Sahyon AS, Longo M, Fernandes LA, Gualberto Junior EC, Novaes VC, et al. Effect of LLLT on autogenous bone grafts in the repair of critical size defects in the calvaria of immunosuppressed rats. J Craniomaxillofac Surg. 2014 Oct;42(7):1196-202. https://doi.org/10.1016/j.jcms.2014.02.008

93. Yan J, Zhang J, Zhang Q, Zhang X, Ji K. Effectiveness of laser adjunctive therapy for surgical treatment of gingival recession with flap graft techniques: a systematic review and meta-analysis. Lasers Med Sci. 2018 May;33(4):899-908. https://doi.org/10.1007/s10103-018-2440-x

94. Wainwright M, Maisch T, Nonell S, Plaetzer K, Almeida A, Tegos GP, et al. Photoantimicrobials-are we afraid of the light? Lancet Infect Dis. 2017 Feb;17(2):e49-55. https://doi.org/10.1016/S1473-3099(16)30268-7

95. Raab O. Uber die wirkung fluorescierenden stoffe auf infusiorien. Z Biol (Münch). 1900;39:524-46.

96. Wainwright M, McLean A. Rational design of phenothiazinium derivatives and photoantimicrobial drug discovery. Dyes Pigments. 2017;136:590-600. https://doi.org/10.1016/i.dyepig.2016.09.015

97. Wilson M. Lethal photosensitisation of oral bacteria and its potential application in the photodynamic therapy of oral infections. Photochem Photobiol Sci. 2004 May;3(5):412-8. https://doi.org/10.1039/b211266c 
98. Lins RX, Andrade AO, Hirata Junior R, Wilson MJ, Lewis MA, Williams DW, et al. Antimicrobial resistance and virulence traits of Enterococcus faecalis from primary endodontic infections. J Dent. 2013 Sep;41(9):779-86. https://doi.org/10.1016/i.jdent.2013.07.004

99. Senna AM, Vieira MM, Machado-de-Sena RM, Bertolin AO, Núñez SC, Ribeiro MS. Photodynamic inactivation of Candida ssp. on denture stomatitis. A clinical trial involving palatal mucosa and prosthesis disinfection. Photodiagn Photodyn Ther. 2018 Jun;22:212-6. https://doi.org/10.1016/i.pdpdt.2018.04.008

100. Haag PA, Steiger-Ronay V, Schmidlin PR. The in vitro antimicrobial efficacy of PDT against periodontopathogenic bacteria. Int J Mol Sci. 2015 Nov;16(11):27327-38. https://doi.org/10.3390/ijms161126027

101. Alvarenga LH, Prates RA, Yoshimura TM, Kato IT, Suzuki LC, Ribeiro MS, et al. Aggregatibacter actinomycetemcomitans biofilm can be inactivated by methylene blue-mediated photodynamic therapy. Photodiagn Photodyn Ther. 2015 Mar;12(1):131-5. https://doi.org/10.1016/i.pdpdt.2014.10.002

102. Rad MR, Pourhajibagher M, Rokn AR, Barikani HR, Bahador A. Effect of antimicrobial photodynamic therapy using indocyanine green doped with chitosan nanoparticles on biofilm formation-related gene expression of Aggregatibacter actinomycetemcomitans. Front Dent. 2019 May-Jun;16(3):187-93. https://doi.org/10.18502/fid.v16i3.1590

103. Bhatti M, MacRobert A, Meghii S, Henderson B, Wilson M. A study of the uptake of toluidine blue O by Porphyromonas gingivalis and the mechanism of lethal photosensitization. Photochem Photobiol. 1998 Sep;68(3):370-6. https://doi.org/10.1111/j.1751-1097.1998.tb09694.x

104. Tavares LJ, Avila ED, Klein MI, Panariello BH, Spolidório DM, Pavarina AC. Antimicrobial photodynamic therapy alone or in combination with antibiotic local administration against biofilms of Fusobacterium nucleatum and Porphyromonas gingivalis. J Photochem Photobiol B. 2018 Nov;188:135-45. https://doi.org/10.1016/i.jphotobiol.2018.09.010

105. Nuernberg MA, Miessi DMJ, Ivanaga CA, Bocalon Olivo M, Ervolino E, Garcia VG, et al. Influence of antimicrobial photodynamic therapy as an adjunctive to scaling and root planing on alveolar bone loss: a systematic review and meta-analysis of animal studies. Photodiagn Photodyn Ther. 2019 Mar;25:354-63. https://doi.org/10.1016/i.pdpdt.2019.01.020

106. Fernandes LA, Almeida JM, Theodoro LH, Bosco AF, Nagata MJ, Martins TM, et al. Treatment of experimental periodontal disease by photodynamic therapy in immunosuppressed rats. J Clin Periodontol. 2009 Mar;36(3):219-28. https://doi.org/10.1111/j.1600-051X.2008.01355.x

107. Garcia VG, Longo M, Fernandes LA, Gualberto Junior EC, Santinoni CS, Bosco AF, et al. Treatment of experimental periodontitis in rats using repeated adjunctive antimicrobial photodynamic therapy. Lasers Med Sci. 2013 Jan;28(1):143-50. https://doi.org/10.1007/s10103-012-1099-y

108. Garcia VG, Longo M, Gualberto Júnior EC, Bosco AF, Nagata MJ, Ervolino E, et al. Effect of the concentration of phenothiazine photosensitizers in antimicrobial photodynamic therapy on bone loss and the immune inflammatory response of induced periodontitis in rats. J Periodontal Res. 2014 Oct;49(5):584-94. https://doi.org/10.1111/ire.12138

109. Theodoro LH, Ferro-Alves ML, Longo M, Nuernberg MA, Ferreira RP, Andreati A, et al. Curcumin photodynamic effect in the treatment of the induced periodontitis in rats. Lasers Med Sci. 2017 Nov;32(8):1783-91. https://doi.org/10.1007/s10103-017-2261-3

110. Longo M, Gouveia Garcia V, Ervolino E, Ferro Alves ML, Duque C, Wainwright M, et al. Multiple aPDT sessions on periodontitis in rats treated with chemotherapy: histomorphometrical, immunohistochemical, immunological and microbiological analyses. Photodiagn Photodyn Ther. 2019 Mar;25:92-102. https://doi.org/10.1016/i.pdpdt.2018.11.014

111. Nuernberg MAA, Wainwright M, Miessi DMJ, Scalet V, Olivo MB, Ervolino E, et al. Effects of butyl toluidine blue photosensitizer on antimicrobial photodynamic therapy for experimental periodontitis treatment in rats. Photodiagnosis Photodyn Ther. 2020:101868. https://doi.org/10.1016/i.pdpdt.2020.101868

112. Braun A, Dehn C, Krause F, Jepsen S. Short-term clinical effects of adjunctive antimicrobial photodynamic therapy in periodontal treatment: a randomized clinical trial. J Clin Periodontol. 2008 Oct;35(10):877-84. https://doi.org/10.1111/j.1600-051X.2008.01303.x

113. Christodoulides N, Nikolidakis D, Chondros P, Becker J, Schwarz F, Rössler R, et al. Photodynamic therapy as an adjunct to non-surgical periodontal treatment: a randomized, controlled clinical trial. J Periodontol. 2008 Sep;79(9):1638-44. https://doi.org/10.1902/jop.2008.070652

114. Ge L, Shu R, Li Y, Li C, Luo L, Song Z, et al. Adjunctive effect of photodynamic therapy to scaling and root planing in the treatment of chronic periodontitis. Photomed Laser Surg. 2011 Jan;29(1):33-7. https://doi.org/10.1089/pho.2009.2727

115. Petelin M, Perkič K, Seme K, Gašpirc B. Effect of repeated adjunctive antimicrobial photodynamic therapy on subgingival periodontal pathogens in the treatment of chronic periodontitis. Lasers Med Sci. 2015 Aug;30(6):1647-56. https://doi.org/10.1007/s10103-014-1632-2

116. Theodoro LH, Silva SP, Pires JR, Soares GH, Pontes AE, Zuza EP, et al. Clinical and microbiological effects of photodynamic therapy associated with nonsurgical periodontal treatment. A 6-month follow-up. Lasers Med Sci. 2012 Jul;27(4):687-93. https://doi.org/10.1007/s10103-011-0942-x

117. Theodoro LH, Assem NZ, Longo M, Alves ML, Duque C, Stipp RN, et al. Treatment of periodontitis in smokers with multiple sessions of antimicrobial photodynamic therapy or systemic antibiotics: A randomized clinical trial. Photodiagn Photodyn Ther. 2018 Jun;22:217-22. https://doi.org/10.1016/i.pdpdt.2018.04.003 
LASER in periodontal treatment: is it an effective treatment or science fiction?

118. Theodoro LH, Lopes AB, Nuernberg MA, Cláudio MM, Miessi DM, Alves ML, et al. Comparison of repeated applications of aPDT with amoxicillin and metronidazole in the treatment of chronic periodontitis: a short-term study. J Photochem Photobiol B. 2017 Sep;174:3649. https://doi.org/10.1016/i.jphotobiol.2017.08.012

119. Cláudio MM. Efeitos da terapia fotodinâmica antimicrobiana (aPDT) em múltiplas sessões no tratamento da periodontite em pacientes diabéticos tipo 2: estudo clínico controlado randomizado. Dissertação (Mestrado) - Universidade Estadual Paulista, Araçatuba, 2018.

120. Lulic M, Leiggener Görög I, Salvi GE, Ramseier CA, Mattheos N, Lang NP. One-year outcomes of repeated adjunctive photodynamic therapy during periodontal maintenance: a proof-of-principle randomized-controlled clinical trial. J Clin Periodontol. 2009 Aug;36(8):661-6. https://doi.org/10.1111/j.1600-051X.2009.01432.x

121. Campos GN, Pimentel SP, Ribeiro FV, Casarin RC, Cirano FR, Saraceni CH, et al. The adjunctive effect of photodynamic therapy for residual pockets in single-rooted teeth: a randomized controlled clinical trial. Lasers Med Sci. 2013 Jan;28(1):317-24. https://doi.org/10.1007/s10103-012-1159-3

122. Kolbe MF, Ribeiro FV, Luchesi VH, Casarin RC, Sallum EA, Nociti Junior FH, et al. Photodynamic therapy during supportive periodontal care: clinical, microbiologic, immunoinflammatory, and patient-centered performance in a split-mouth randomized clinical trial. J Periodontol. 2014 Aug;85(8):e277-86. https://doi.org/10.1902/jop.2014.130559

123. Campanile VSM, Giannopoulou C, Campanile G, Cancela JA, Mombelli A. Single or repeated antimicrobial photodynamic therapy as adjunct to ultrasonic debridement in residual periodontal pockets: clinical, microbiological, and local biological effects. Lasers Med Sci. 2015 Jan;30(1):27-34. https://doi.org/10.1007/s10103-013-1337-y

124. Carvalho VF, Andrade PV, Rodrigues MF, Hirata MH, Hirata RD, Pannuti CM, et al. Antimicrobial photodynamic effect to treat residual pockets in periodontal patients: a randomized controlled clinical trial. J Clin Periodontol. 2015 May;42(5):440-7. https://doi.org/10.1111/jcpe.12393

125. Ivanaga CA, Miessi DM, Nuernberg MA, Claudio MM, Garcia VG, Theodoro LH. Antimicrobial photodynamic therapy (aPDT) with curcumin and LED, as an enhancement to scaling and root planing in the treatment of residual pockets in diabetic patients: a randomized and controlled split-mouth clinical trial. Photodiagn Photodyn Ther. 2019;27:388-95. https://doi.org/10.1016/i.pdpdt.2019.07.005

126. Chatzopoulos GS, Doufexi AE. Photodynamic therapy in the treatment of aggressive periodontitis: A systematic review. Med Oral Patol Oral Cir Bucal. 2016 Mar;21(2):e192-200. https://doi.org/10.4317/medoral.21046

127. Joseph B, Janam P, Narayanan S, Anil S. Is Antimicrobial Photodynamic Therapy Effective as an Adjunct to Scaling and Root Planing in Patients with Chronic Periodontitis? A Systematic Review. Biomolecules. 2017 Nov;7(4):79. https://doi.org/10.3390/biom7040079

128. Xue D, Zhao Y. Clinical effectiveness of adjunctive antimicrobial photodynamic therapy for residual pockets during supportive periodontal therapy: A systematic review and meta-analysis. Photodiagn Photodyn Ther. 2017 Mar; 17:127-33. https://doi.org/10.1016/i.pdpdt.2016.11.011

129. Azaripour A, Dittrich S, Van Noorden CJ, Willershausen B. Efficacy of photodynamic therapy as adjunct treatment of chronic periodontitis: a systematic review and meta-analysis. Lasers Med Sci. 2018 Feb;33(2):407-23. https://doi.org/10.1007/s10103-017-2383-7

130. Chambrone L, Wang HL, Romanos GE. Antimicrobial photodynamic therapy for the treatment of periodontitis and peri-implantitis: an American Academy of Periodontology best evidence review. J Periodontol. 2018 Jul;89(7):783-803. https://doi.org/10.1902/jop.2017.170172

131. Akram Z. How effective is adjunctive antimicrobial photodynamic therapy in treating deep periodontal pockets in periodontal disease? $\mathrm{A}$ systematic review. J Investig Clin Dent. 2018 Nov;9(4):e12345. https://doi.org/10.1111/jicd.12345

132. Franco TP, Santos AP, Canabarro A. The effects of repeated applications of antimicrobial photodynamic therapy in the treatment of residual periodontal pockets: a systematic review. Lasers Med Sci. 2019 Jul;34(5):855-63. https://doi.org/10.1007/s10103-018-02703-2

133. Javed F, Salehpoor D, Al-Dhafeeri T, Yousuf M, Malmstrom H, Khan J, et al. Is adjunctive photodynamic therapy more effective than scaling and root planing alone in the treatment of periodontal disease in hyperglycemic patients? A systematic review. Photodiagn Photodyn Ther. 2018 Jun;22:1-6. https://doi.org/10.1016/i.pdpdt.2018.02.012

134. Akram Z, Raffat MA, Saad Shafqat S, Mirza S, Ikram S. Clinical efficacy of photodynamic therapy as an adjunct to scaling and root planing in the treatment of chronic periodontitis among cigarette smokers: A systematic review and meta-analysis. Photodiagn Photodyn Ther. 2019 Jun;26:334-41. https://doi.org/10.1016/i.pdpdt.2019.04.027

135. Souza EQM, Rocha TE, Toro LF, Guiati IZ, Ervolino E, Garcia VG, et al. Antimicrobial photodynamic therapy compared to systemic antibiotic therapy in non-surgical treatment of periodontitis: systematic review and meta-analysis. Photodiagnosis Photodyn Ther. 2020;31:101808. https://doi.org/10.1016/i.pdpdt.2020.101808 